\title{
Multi-scale modeling of angiotensin II induced neuronal regulatory mechanisms in the brain
}

\author{
Rajanikanth Vadigepalli*, Dirk Fey and James S Schwaber
}

\author{
Address: Department of Pathology, Thomas Jefferson University, Philadelphia, PA 19107, USA \\ Email: Rajanikanth Vadigepalli* - raj@mail.dbi.tju.edu \\ * Corresponding author
}

from Seventeenth Annual Computational Neuroscience Meeting: CNS*2008

Portland, OR, USA. 19-24 July 2008

Published: II July 2008

BMC Neuroscience 2008, 9(SuppI I):P47 doi:I0.I I86/I47I-2202-9-SI-P47

This abstract is available from: http://www.biomedcentral.com/I47I-2202/9/SI/P47

(c) 2008 Vadigepalli et al; licensee BioMed Central Ltd.

\section{Introduction}

In this study, we focus on the multi-scale dynamics involved in neuronal regulatory mechanisms at two levels: signaling dynamics elicited by neuropeptide receptors and their crosstalk with the electrophysiological processes. The particular system considered is the angiotensin II (AngII) receptor type 1 (AT1R) signaling and modulation of electrical activity in the cardiorespiratory control neurons in the brainstem. AngII acting via AT1R in the brainstem influences the baroreceptor reflexes thus modulating cardiac and respiratory homeostasis. Stimulation of brainstem neurons by AngII has been shown to result in dynamic changes in excitability, a neuronal adaptation lasting several minutes, and this response is mediated by AT1R activated by AngII [1].

\section{Methods}

We have developed a multi-scale mathematical model that integrates a detailed kinetic reaction model of the AT1R mediated signaling pathway with a Hodgkin-Huxley-like model of the membrane electrophysiology. Our model includes Gq-protein-mediated activation of $\mathrm{Ca}^{2+}$ dependent enzymes Protein Kinase C (PKC) and Calcium/calmodulin-dependent protein kinase II (CaMKII). The electrical model contains channels that are relevant to cardiorespiratory neurons in the brainstem [2]. The key aspects of the integrated model include: (1) change in the conductance of potassium channels upon phosphorylation by PKC and CaMKII, (2) voltage dependence of $\mathrm{Na}^{+}-$ $\mathrm{Ca}^{2+}$ exchanger, and (3) compartmentalized $\mathrm{Ca}^{2+}$ balance accounting for signaling-mediated and voltage-dependent mechanisms. The parameters were identified either by fit- ting to experimental data summarized in [3], or via sensitivity analyses searching for robust parameter ranges.

\section{Results}

In order to identify contribution of each of PKC and CaMKII, we simulated a 'blockade' of channel phosphorylation by either kinase (Figure 1). Blocking PKC-dependent modulation resulted in a faster, but delayed, increase in firing rate. However, blocking CaMKII-dependent phosphorylation had an effect on overall 'gain' but not on the pattern of neuronal excitability dynamics. Another key hypothesis of the integrated model is compartmentaliza-

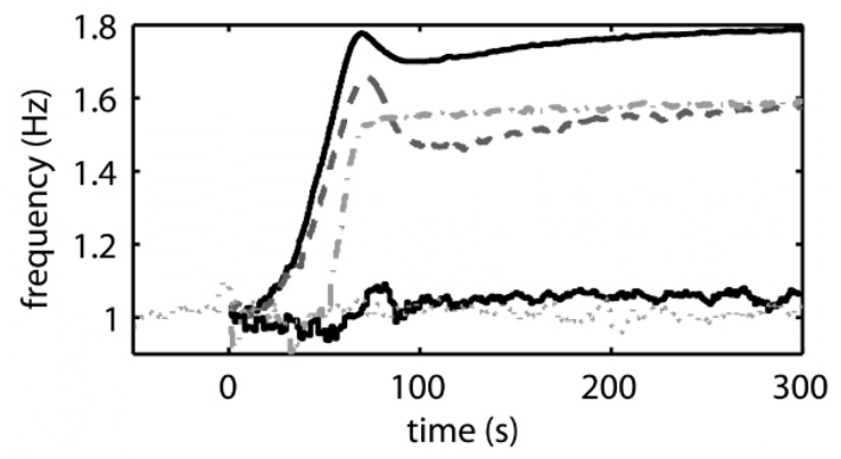

Figure I

Response of the integrated model to $100 \mathrm{nM}$ Angll stimulus. Nominal response (upper solid line), phosphorylation by CaMKII is blocked (dashed), phosphorylation by PKC is blocked (dash-dotted), phosphorylation by PKC and CaMKII are blocked (lower solid line), no Angll stimulus (dotted). 
tion of $\mathrm{Ca}^{2+}$ levels between membrane and cytosol (with the two interacting via a buffer) without which the system cannot exhibit AngII-elicited increase in neuronal excitability. Sensitivity analysis revealed significant effects of a number of signaling reactions on the overall $\mathrm{Ca}^{2+}$ balance. These hypotheses form the basis for experimental validation of the key mechanisms via pharmacological modulators of kinases and channels.

\section{Acknowledgements}

Research Support: NIH/HLB R33 HL08736I to JSS

\section{References}

I. Li YW, Guyenet PG: Angiotensin II decreases a resting K+ conductance in rat bulbospinal neurons of the $\mathrm{Cl}$ area. Circ Res 1996, 78(2):274-282.

2. Rybak IA, Paton JF, Schwaber JS: Modeling neural mechanisms for genesis of respiratory rhythm and pattern. I. Models of respiratory neurons. J Neurophysiol 1997, 77(4): 1994-2006.

3. Sumners C, Fleegal MA, Zhu M: Angiotensin ATI receptor signalling pathways in neurons. Clin Exp Pharmacol Physiol 2002, 29(5-6):483-490.
Publish with BiolMed Central and every scientist can read your work free of charge

"BioMed Central will be the most significant development for disseminating the results of biomedical research in our lifetime. "

Sir Paul Nurse, Cancer Research UK

Your research papers will be:

- available free of charge to the entire biomedical community

- peer reviewed and published immediately upon acceptance

- cited in PubMed and archived on PubMed Central

- yours - you keep the copyright

Submit your manuscript here:

http://www.biomedcentral.com/info/publishing_adv.asp 